\title{
Lymphoepithelial Carcinoma in the Lateral Tongue: The Case Report
}

\author{
Sawako Ono ${ }^{1,2}, *$, Hidenori Marunaka ${ }^{3}$, Hiroyuki Yanai ${ }^{4}$, Hotaka Kawai ${ }^{5}$, Kiyofumi Takabatake ${ }^{5}$, \\ Kenji Nishida ${ }^{4}$, Tomohiro Toji ${ }^{4}$, Keisuke Nakano ${ }^{5}$, Hitoshi Nagatsuka ${ }^{5}$ and Tadashi Yoshino ${ }^{2}$ \\ 1 Department of Pathology, Kagawa Prefectural Central Hospital, Takamatsu 760-8557, Japan \\ 2 Department of Pathology and Medicine, Graduate School of Medicine, Dentistry and Pharmaceutical \\ Sciences, Okayama University, Okayama 700-0914, Japan; yoshino@md.okayama-u.ac.jp \\ 3 Department of Otolaryngology Head and Neck Surgery, Okayama University Hospital, \\ Okayama 700-0914, Japan; marunaka@okayama-u.ac.jp \\ 4 Department of Pathology, Okayama University Hospital, Okayama 700-0914, Japan; \\ yanaih@md.okayama-u.ac.jp (H.Y.); fabbito12@gmail.com (K.N.); st27051@yahoo.co.jp (T.T.) \\ 5 Department of Oral Pathology and Medicine, Graduate School of Medicine, Dentistry and Pharmaceutical \\ Sciences, Okayama University, Okayama 700-0914, Japan; de18018@s.okayama-u.ac.jp (H.K.); \\ gmd422094@s.okayama-u.ac.jp (K.T.); pir19btp@okayama-u.ac.jp (K.N.); jin@okayama-u.ac.jp (H.N.) \\ * Correspondence: de19008@s.okayama-u.ac.jp; Tel.: +81-86-235-6651; Fax: +81-86-235-6654
}

Citation: Ono, S.; Marunaka, H.; Yanai, H.; Kawai, H.; Takabatake, K.; Nishida, K.; Toji, T.; Nakano, K.; Nagatsuka, H.; Yoshino, T. Lymphoepithelial Carcinoma in the Lateral Tongue: The Case Report. Reports 2021, 4, 24. https://doi.org/ $10.3390 /$ reports 4030024

Academic Editor: Toshio Hattori

Received: 26 April 2021

Accepted: 11 August 2021

Published: 12 August 2021

Publisher's Note: MDPI stays neutral with regard to jurisdictional claims in published maps and institutional affiliations.

\begin{abstract}
Lymphoepithelial carcinoma (LEC) of the tongue is a rare subtype of squamous cell carcinoma. Histologically, it is an undifferentiated carcinoma with rich lymphocyte and plasma cell infiltration. The most common location for LEC in the head and neck is the salivary glands, and LEC of the oral cavity is extremely rare. The second case report of LEC in the lateral tongue is presented. In addition, a review of the literature was performed, and the relationship between LEC and Epstein-Barr virus infection was considered.
\end{abstract}

Keywords: Lymphoepithelial carcinoma; oral cavity; lateral tongue

\section{Introduction}

Lymphoepithelial carcinoma (LEC) is a squamous cell carcinoma morphologically similar to non-keratinizing nasopharyngeal carcinoma, undifferentiated subtype [1]. Schminke first described LEC of the nasopharynx in 1921 [2]. Histologically, LEC consists of atypical epithelial-derived cells that have pale cytoplasm and large, round vesicular nuclei. It is characterized by lymphoid cells breaking up the tumor into tiny aggregates. Epstein-Barr virus (EBV) is associated with head and neck LEC (HNLEC).

HNLEC is a tumor diagnosed most commonly in the salivary glands, and only 18 cases in the oral cavity appear to have been reported so far. To the best of our knowledge, no case of LEC in the lateral tongue has been reported in the English literature. A case of LEC in the lateral tongue is presented, along with a review of the literature on oral LEC and a discussion of the relationship between oral LEC and EBV infection.

\section{Case Report}

An 82-year-old man with a previous history of alcohol and tobacco use and esophageal cancer 8 years earlier noticed a mass on the left edge of the tongue. Malignancy was suspected on examination of a biopsy specimen, and he was referred to our hospital. On clinical examination, a hard, slightly bulging mass with a smooth surface, approximately $2 \times 1 \mathrm{~cm}^{2}$, was found (Figure 1a). The tumor was localized in the posterior edge of the left edge of the tongue, and there was no cervical lymph node enlargement on computed tomography (CT) (Figure 1b). The nasal cavity, nasopharynx, and larynx appeared normal on endoscopy. The tumor was resected, and macroscopically, the excised tumor was a pale yellowish, solid mass, $1.7 \times 1.0 \times 1.2 \mathrm{~cm}^{3}$ in size (Figure 2). Histologically, the tumor cells 
showed proliferation of pale staining, cohesive epithelial cells with prominent surrounding and infiltrating lymphocytes (Figure 3). The tumor cells are polygonal and contained large round vesicular nuclei with prominent nucleoli. No keratinization was found in the tumor, and was similar to nasopharyngeal carcinoma. On immunohistochemistry, the tumor cells were positive for cytokeratin AE1/AE3, p40, and p53. On in situ hybridization, the epithelial cells were negative for EBV-encoded small RNA (EBER) (Figures 4 and 5). The diagnosis of LEC was made. After surgery, no recurrence was observed at the 7-month follow-up visit.
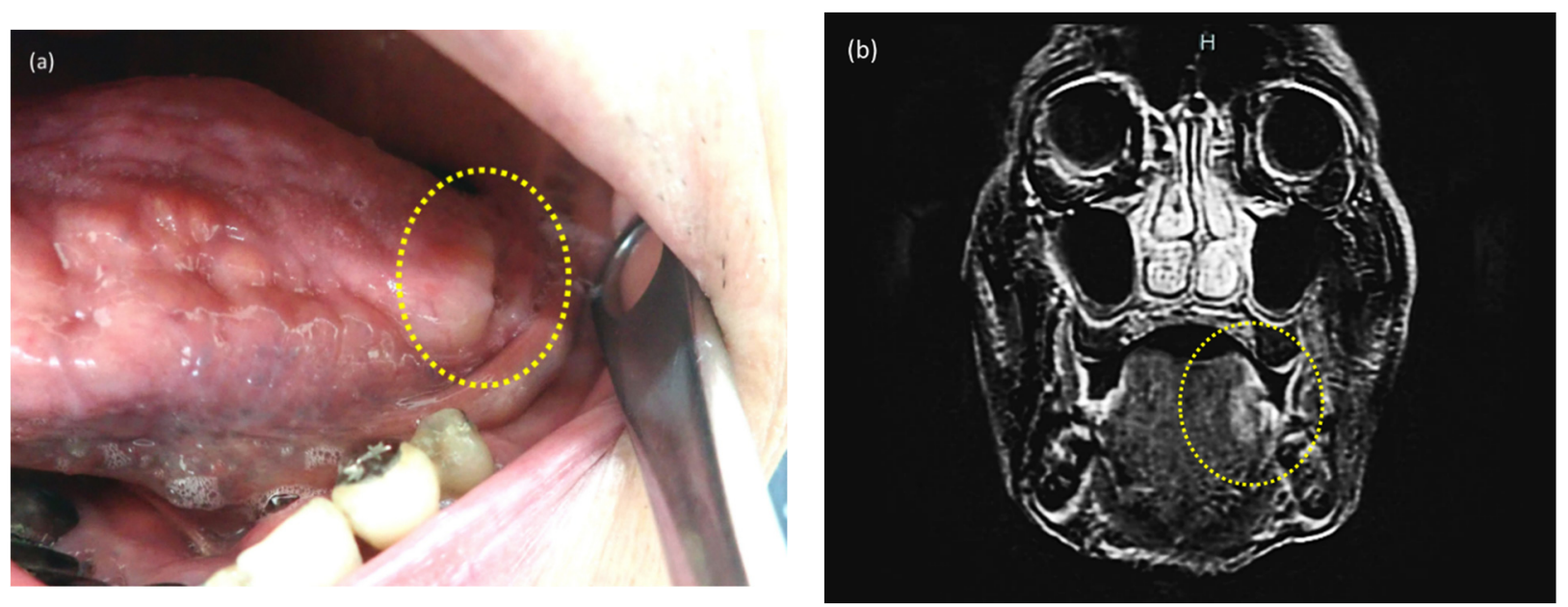

Figure 1. Gross findings of the tumor. (a)The tumor is seen in the posterior edge of the left side of the tongue. (b)The tumor is localized in the left side of the tongue.

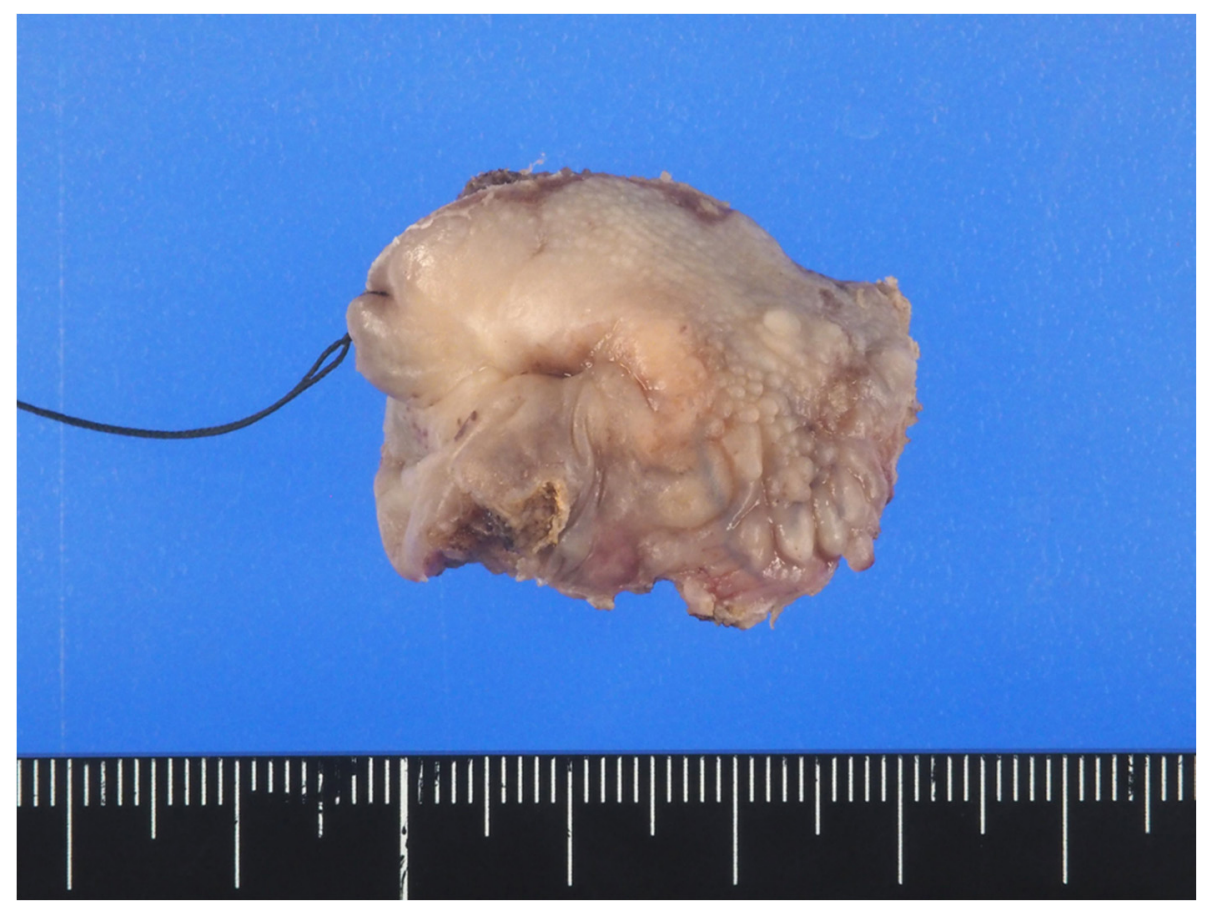

Figure 2. Gross findings of the resected material that view from the left. The tumor is in the anterior vallate papilla. The surface of the tumor is smooth, and the central depression of the tumor is the biopsy scar. 

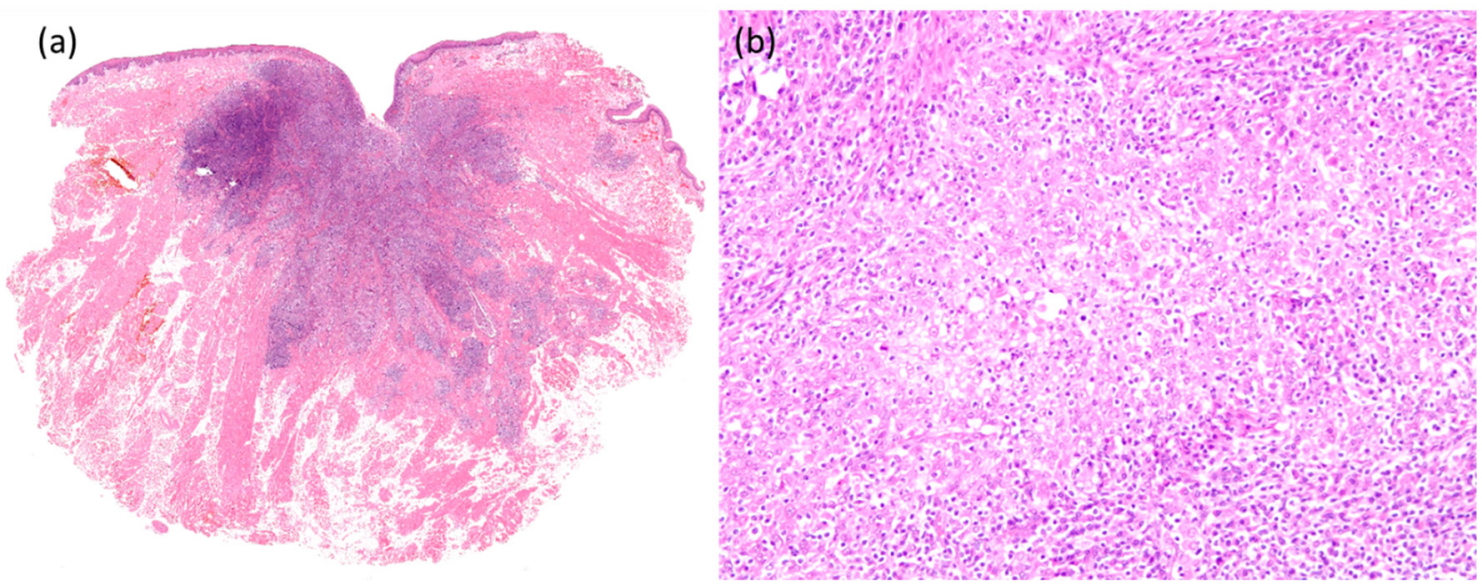

Figure 3. Histological findings of the tumor. (a) The tumor infiltrates the muscles of tongue (20×). (b) The tumor exhibits a cluster of light staining neoplastic cells with abundant lymphocytic stromal $(100 \times)$.

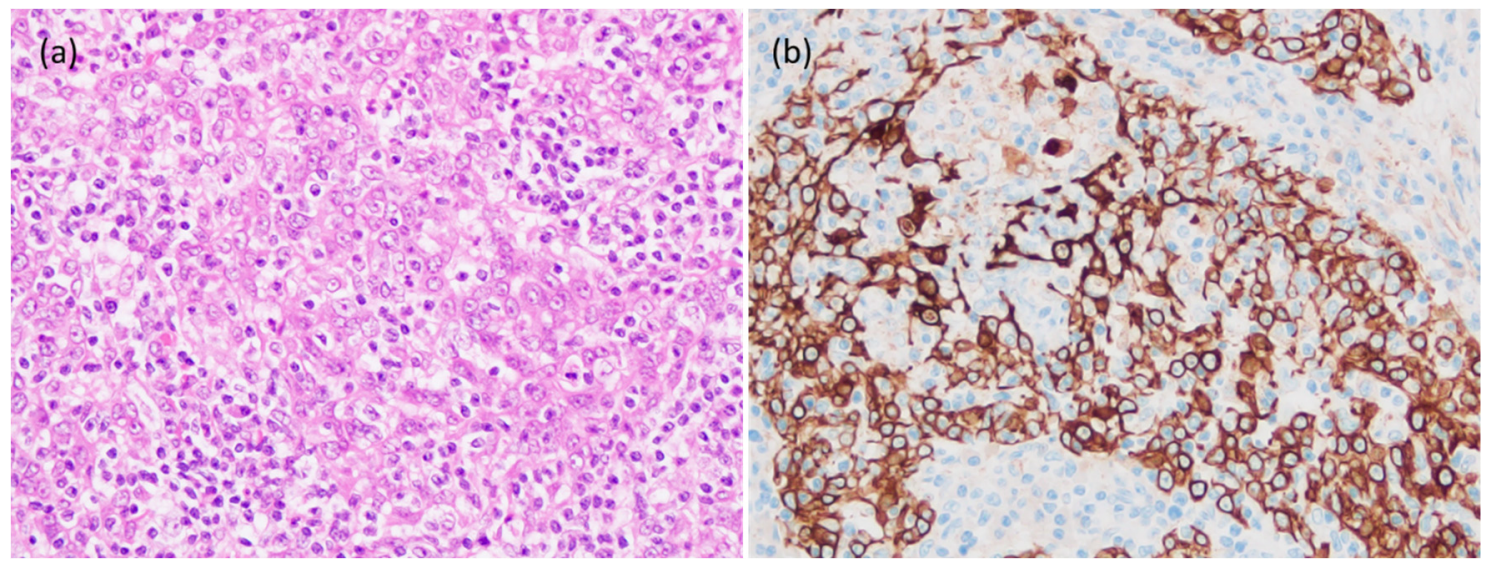

Figure 4. Histological and immunohistochemical findings of the tumor. (a) The tumor cells are polygonal with enlarged vesicular nucleoli and lightly eosinophilic cytoplasm, and abundant infiltration of lymphocytes is seen $(200 \times)$. (b) The tumor cells are positive for cytokeratin AE1/AE3 $(200 \times)$. 


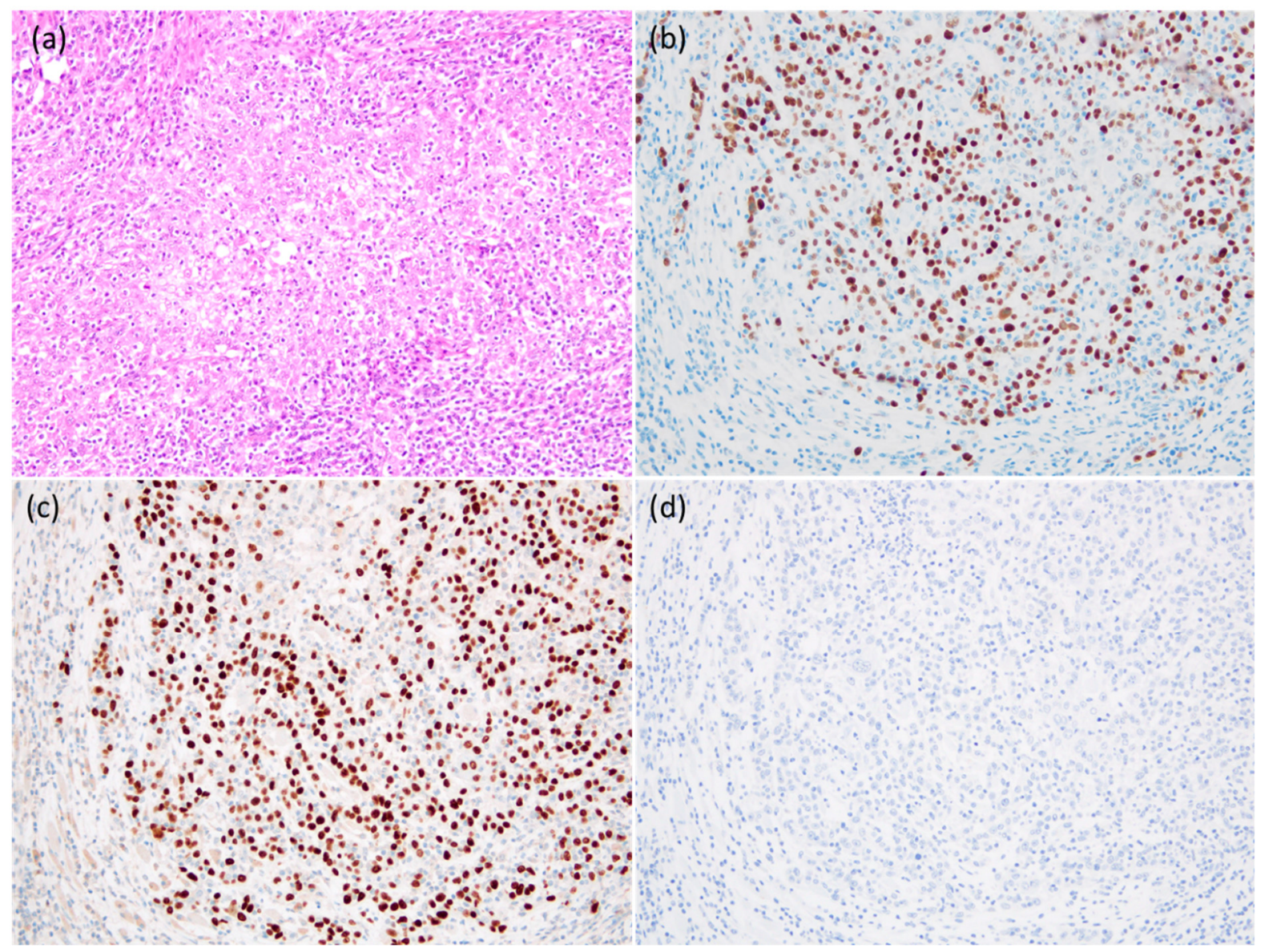

Figure 5. Histological, immunohistochemical and in situ hybridization findings of the tumor. (a) Histological finding of the tumor $(100 \times)$. On immunohistochemistry, p53 (b) $(100 \times)$, and p40 $(\mathbf{c})(100 \times)$. The tumor cells are negative on EBER (d) $(100 \times)$ in situ hybridization.

\section{Discussion}

LEC is a subset of poorly differentiated squamous cell carcinoma with intermingled lymphocytes. LEC outside of the nasopharynx is rare, and only 18 cases of oral LEC have been reported (Table 1). Oral LEC developed commonly in the minor salivary gland, lip, and palate. This is the second report of LEC arising in the lateral tongue. The age of patients ranged from 11 to 82 years (average 56.4 years), and there was no sex predilection. All tumors were within $3 \mathrm{~cm}$ (range: 0.5 to $2.6 \mathrm{~cm}$ ) in size. Six patients (33.3\%) had metastases to the cervical lymph nodes. Although one patient who refused treatment died of tumor 34 months after diagnosis, the prognosis of patients with oral LEC was excellent.

Histologically, the present case showed proliferation of non-keratinized epithelial cells with massive infiltration of lymphocytes. On immunohistochemical examination, tumor cells were diffusely positive for cytokeratin AE1/AE3 and p40. These results confirm the character of the tumor cells as squamous epithelium.

Previous reports showed an association between EBV and oral LEC, especially in Asian cases. Of the 12 Asian cases, 9 (75\%) were positive. In contrast, no cases in North and South America, Europe, and Africa showed an association with EBV. In the present case, the tumor cells were negative on EBER in situ hybridization. 
Table 1. Summary of previous and current reports of LEC in the oral cavity. M: Male, F: Female, EBV: Epstein-Barr virus, NM: not mentioned, +: positive, -: negative, LN: lymph node, S: surgery, R: radiotherapy, C: chemotherapy.

\begin{tabular}{|c|c|c|c|c|c|c|c|c|c|c|}
\hline Study & $\begin{array}{c}\text { Age } \\
\text { (Years) }\end{array}$ & Gender & Country & EBV & Site & Size & Metastasis & Treatment & $\begin{array}{l}\text { Follow-Up } \\
\text { (Month) }\end{array}$ & $\begin{array}{c}\text { Residual, } \\
\text { Metastasis }\end{array}$ \\
\hline Ahuja (1999) [3] & 63 & $\mathrm{M}$ & China & + & Roof of oral cavity & $2.5 \mathrm{~cm}$ & NM & NM & NM & NM \\
\hline \multirow{4}{*}{ Chow (2002) [4] } & 47 & $\mathrm{~F}$ & & + & Palatinum & NM & cervical LN & NM & NM & NM \\
\hline & 58 & M & China & + & Palatinum & $2.0 \mathrm{~cm}$ & cervical LN & $\mathrm{R}$ & 30 & No \\
\hline & 56 & $\mathrm{~F}$ & & + & Palatinum & $1.5 \mathrm{~cm}$ & No & $\mathrm{R}$ & 12 & No \\
\hline & 80 & $\mathrm{~F}$ & & + & Retromolar region & $\mathrm{NM}$ & cervical LN & $\begin{array}{l}\text { patient } \\
\text { refused }\end{array}$ & 34 & Died \\
\hline $\mathrm{Lu}(2005)[5]$ & 50 & $\mathrm{~F}$ & Taiwan & + & $\begin{array}{l}\text { Minor salivary } \\
\text { gland, cheek }\end{array}$ & $2 \times 1.6 \times 1 \mathrm{~cm}^{3}$ & No & $\mathrm{S}+\mathrm{R}$ & 120 & No \\
\hline $\begin{array}{c}\text { Tanuja (2008) } \\
\text { [6] }\end{array}$ & 11 & M & India & + & Mandible & NM & cervical LN & $C+R$ & 36 & No \\
\hline Hsieh (2010) [7] & 50 & M & Taiwan & + & Buccal mucosa & $2 \mathrm{~cm}$ & No & $C+R$ & NM & $\begin{array}{l}\text { residual } \\
\text { tumor }\end{array}$ \\
\hline Zeng (2015) [8] & 38 & $\mathrm{~F}$ & China & + & Hard palate & $\begin{array}{c}2.6 \times 2.4 \times \\
1.7 \mathrm{~cm}^{3}\end{array}$ & No & S & 12 & No \\
\hline Weiss (1989) [9] & 64 & M & $\begin{array}{l}\text { United } \\
\text { States of } \\
\text { America }\end{array}$ & - & Floor of mouth & NM & NM & NM & NM & NM \\
\hline $\begin{array}{l}\text { Worley (1997) } \\
\text { [10] }\end{array}$ & 69 & $\mathrm{~F}$ & $\begin{array}{l}\text { United } \\
\text { States of } \\
\text { America }\end{array}$ & - & $\begin{array}{l}\text { subepithelial mass } \\
\text { in the left buccal } \\
\text { area }\end{array}$ & $0.5 \mathrm{~cm}$ & cervical LN & $S+R$ & 12 & No \\
\hline $\begin{array}{l}\text { Mahomed } \\
\text { (2008) [11] }\end{array}$ & 73 & M & $\begin{array}{l}\text { South } \\
\text { Africa }\end{array}$ & - & Lower lip & $1 \times 1 \mathrm{~cm}^{2}$ & No & S & 20 & No \\
\hline $\begin{array}{c}\text { Rytkönen (2011) } \\
\text { [1] }\end{array}$ & 30 & M & Finland & - & Maxilla & NM & No & $S+R$ & 11 & No \\
\hline $\begin{array}{c}\text { Dardo (2012) } \\
\text { [12] }\end{array}$ & 56 & M & Italy & - & $\begin{array}{l}\text { Minor salivary } \\
\text { gland } \\
\text { and upper lip }\end{array}$ & $2.5 \mathrm{~cm}$ & No & $\mathrm{S}$ & 24 & No \\
\hline $\begin{array}{c}\text { Gultekin (2014) } \\
\text { [13] }\end{array}$ & 41 & M & Turkey & - & Lower lip & $1 \mathrm{~cm}$ & cervical LN & $C+R$ & 36 & No \\
\hline $\begin{array}{c}\text { Almeida (2019) } \\
{[14]}\end{array}$ & 82 & $\mathrm{~F}$ & Brasil & - & Lower lip & NM & No & s & 24 & No \\
\hline $\begin{array}{c}\text { Takeda (2021) } \\
{[15]}\end{array}$ & 72 & $\mathrm{~F}$ & Japan & - & left tongue edge & $1.2 \times 0.6 \mathrm{~cm}^{2}$ & No & $\mathrm{S}$ & 12 & No \\
\hline Present case & 82 & M & Japan & - & left tongue edge & $\begin{array}{l}1.7 \times 1.0 \times \\
1.2 \mathrm{~cm}^{3}\end{array}$ & No & S & 7 & No \\
\hline $\begin{array}{c}\text { Hsiung (2005) } \\
\text { [16] }\end{array}$ & 50 & F & Taiwan & NM & $\begin{array}{l}\text { Minor salivary } \\
\text { gland } \\
\text { in right buccal area }\end{array}$ & $\mathrm{NM}$ & No & $S+R$ & 116.5 & NM \\
\hline
\end{tabular}

The tumor cells of the present case showed overexpression of p53. This finding suggests that mutation of TP53 may play a key role in carcinogenesis of this tumor. In the previous studies, p53 status was studied in only two cases. One case with EBV showed p53 expression in only $25 \%$ of the tumor cells, suggesting wild type [5]. In contrast, one EBVnegative LEC showed overexpression of p53 on immunohistochemistry [14]. Although the number of cases is limited, there may be different mechanisms of tumorigenesis in oral LEC.

Lymph node metastasis was present in 6 of 18 cases, and it was more common in EBV-positive cases. The EBV status of oral LEC may have some role in nodal metastasis.

In conclusion, the second case of LEC in the lateral tongue was presented. This EBVnegative case might have been caused by TP53 mutation, another possible mechanism of tumorigenesis of oral LEC. To identify prognostic factors, study of additional cases is needed.

Author Contributions: S.O.: pathology fellow responsible for working up the case. Write-up of the manuscript and final submission. H.M.: Otolaryngology pathology assistant professor contributed to review the manuscript. H.Y.: pathology professor responsible for the interpretation and final diagnosis of case. H.K., K.T., and K.N. (Keisuke Nakano): Oral pathology assistant professor responsible for interpretation, review, and editing of final manuscript. T.T., and K.N. (Kenji Nishida): pathology assistant professor contributed to the data collection. H.N.: oral pathology professor, consultant during the interpretation and get-ting to the final diagnosis. T.Y.: pathology professor, reviewed manuscript. All authors have read and agreed to the published version of the manuscript.

Funding: This research received no external funding. 
Institutional Review Board Statement: Not applicable.

Informed Consent Statement: Not applicable.

Conflicts of Interest: None of the authors have any conflicts of interest to declare.

\section{References}

1. Rytkönen, A.E.; Hirvikoski, P.P.; Salo, T.A. Lymphoepithelial Carcinoma: Two Case Reports and a Systematic Review of Oral and Sinonasal Cases. Head Neck Pathol. 2011, 5, 327-334. [CrossRef]

2. Schminke, A. Über lymphoepitheliale Geschwü. Beitr. Pathol. Anat. 1921, 68, 161-170.

3. Ahuja, A.T.; Teo, P.M.; To, K.F.; King, A.D.; Metreweli, C. Palatal Lymphoepitheliomas and a review of head and neck lymphoepitheliomas. Clin. Radiol. 1999, 54, 289-293. [CrossRef]

4. Chow, T.L.; Chow, T.K.; Lui, Y.H.; Sze, W.M.; Yuen, N.W.F.; Kwok, S.P.Y. Lymphoepithelioma-like carcinoma of oral cavity: Report of three cases and literature review. Int. J. Oral. Maxillofac. Surg. 2002, 31, 212-218. [CrossRef] [PubMed]

5. Lu, S.Y.; Huang, C.C.; Hsiung, C.Y.; Eng, H.L.; Huang, H.Y. Primary lymphoepithelioma-like carcinoma of minor salivary gland: A case report with immunohistochemical and in situ hybridization studies. Head Neck. 2006, 28, 182-186. [CrossRef] [PubMed]

6. Tanuja, S.; Brijesh, A.; Siddhartha, L.; Rajan, B.; Shubhada, K.; Purna, K. Epstein-Barr virus-associated lymphoepithelioma-like carcinoma of mandible. Pediatr. Dev. Pathol. 2009, 12, 152-155.

7. Hsieh, M.Y.; Chen, Y.K.; Lin, L.M. Primary buccal lymphoepithelial carcinoma: Report of a case. Cases J. Taomfr. $2010,2,4-11$.

8. Zeng, M.; Li, S.; Fu, J.; Wu, H.; Gao, Y. Primary lymphoepithelial carcinoma of the intraoral minor salivary gland: A case report. Oncol. Lett. 2015, 9, 790-792. [CrossRef] [PubMed]

9. Weiss, L.M.; Movahed, L.A.; Butler, A.E.; Swanson, S.A.; Frierson, H.F., Jr.; Cooper, P.H.; Colby, T.V.; Mills, S.E. Analysis of lymphoepithelioma and lymphoepithelioma-like carcinomas for Epstein-Barr viral genomes by in situ hybridization. Am. J. Surg. Pathol. 1989, 13, 625-631. [CrossRef] [PubMed]

10. Worley, N.K.; Daroca, P.J., Jr. Lymphoepithelial carcinoma of the minor salivary gland. Arch. Otolaryngol. Head Neck Surg. 1997, 123, 638-640. [CrossRef] [PubMed]

11. Mahomed, F.; Grayson, W. A rare case of lymphoepithelial carcinoma of the lip. Oral. Surg. Oral. Med. Oral. Pathol. Oral. Radiol. Endod. 2008, 105, e49-e52. [CrossRef] [PubMed]

12. Dardo, M.; Luigi, L.; Massimiliano, M.; Cristian, C.; Mariarosaria, B.; Alfredo, D.; Alfonso, B. Intraoral lymphoepithelial carcinoma of the minor salivary glands. In Vivo 2012, 26, 1087-1089.

13. Gultekin, M.; Sari, S.Y.; Gunhan, O.; Hosal, S.; Cengiz, M.; Gurkaynak, M. Lymphoepithelial carcinoma of the lower lip: Report of a case. Int. J. Hematol. Oncol. 2014, 24, 70-72. [CrossRef]

14. Almeida, L.Y.; Silveira, H.A.; Silva, E.V.; Barbeiro, C.O.; Paula, J.A.; Bufalino, A.; Ribeiro-Silva, A.; León, J.E. EBV-negative lymphoepithelial-like carcinoma of the lower lip. Autops. Case Rep. 2019, 13, e2020138. [CrossRef] [PubMed]

15. Takeda, D.; Shigeoka, M.; Sugano, T.; Yatagai, N.; Hasegawa, T.; Akashi, M. A Case Report of Tongue Lymphoepithelial Carcinoma with a Histological Diagnostic Dilemma. Diagnostics 2021, 11, 1039. [CrossRef] [PubMed]

16. Hsiung, C.Y.; Huang, C.C.; Wang, C.J.; Huang, E.Y.; Huang, H.Y. Lymphoepithelioma-like carcinoma of salivary glands: Treatment results and failure patterns. Br. J. Radiol. 2006, 79, 52-55. [CrossRef] [PubMed] 